\title{
Marginal in/for Literature: Topographical and Rhetorical
}

Aspects

\author{
Yordan Lyutskanov \\ Academy of Sciences of Bulgaria
}

T am revisiting the theme of a summer school held in Sofia in June 2011. If I had the

opportunity to change that title, I would simply rename it "Literature and marginality". "The marginal in/for literature" has cut off one quite actual thematic focus: the marginality, or marginalisation of literature and literary studies. Some of the participants demonstrated a spontaneous affinity towards this topic.

Having interpreted the title formula, I shall attempt to enlarge on ontology of the marginal with regard to literature. I initiated this task long before the summer school was open, in order to facilitate the structuring of a thematic programme for the school. ${ }^{1}$ When possible, I shall support my considerations with examples from the papers delivered there. ${ }^{2}$

I. Literature fluctuates in its semantic scope. Trying to systematise these fluctuations, I propose to delimitate the following thematic domains:

1. Marginal in/for the literary institution;

2. Marginal in/for the literary text [as a verbal structure];

3. Marginal in/for the book $^{3}$;

4. The marginal as represented/understood/promoted/annihilated/created by literature. ${ }^{4}$

The third domain was gravely underrepresented during the summer school.

Such an important aspect within the first one, especially from Sofia, as marginal literatures ${ }^{5}$ was thematised in one lecture only (Hristov 2011). ${ }^{6}$

II. How are the juxtaposed notions (literature and the marginal) related?

0 . On the one hand, "Marginal for literature" implies that literature is an agent. A relevant idea here is, therefore, the idea that literature creates our (actual, possible, social etc.) life. In fact the formulation helps us to be open for both possibilities: of literature being a real agent, and of being only an instrument.

On the other hand, "Marginal in literature" presumes the interpretation of literature as media or a mediator (a 'window', a 'mirror' - but hinting at a certain materiality and at a consistency of its own). And here two ideas appear to be relevant: first, literature represents, reflects and so on; second, it represents or reflects itself.

It is worth mentioning that our formulation lacks the idea of literature as an object.

1. If we ignore the subtleties of linguistic expression, one of the first interpretative reactions to the formulation would be: What is not important for literature? What remains unnoticed, and what is perceived as unimportant and/or non-central when we read it? And, probably: what remains unattended in the study of literature?

III. What does marginal mean?

1. The thought about the marginal gravely depends on the virtual (and culture-experiential) image of the page with its margins; its conceptualisation depends on what might 
be called the page metaphor. ' (In conceptualising and interpreting marginality, it is difficult to escape from the spatiality of its prototype, the page. Given the experience of the Sofia school, escaping from page's materiality is easier.)

Therefore I think that one more type or, rather, mode of marginality (besides the historical, geographical, linguistic, sociological and aesthetic summarised by György M. Vajda (1983)) regarding literature should be outlined. We could designate it as '-textual' or medial marginality.

The lack or the insufficiency of intention to classify as regards medially/ -textually/ literally marginal literature in Vajda's work could be explained with its strong links with the pre-"topographical turn" humanities. I would suggest that a post-turn work could have speculated on its own spatially engendered conceptualising premises. As for my own preoccupation with aspects of marginality embedded in and developing the page metaphor, it could be linked with the current propulsion of topography-focused investigations in the humanities, despite some puzzling particularities. ${ }^{9}$ What is more important, however, is that the turn opens horizons for converging the quests and queries of medievalists and non-medievalists: this being, at least in Bulgarian literary scholarship, an under-recognised necessity and, memorising the experience of the school, a completely unutilised opportunity. ${ }^{10}$

The marginal could be regarded as a synonym of peripheral. We put now this possibility aside. The "marginal" and the "peripheral" could be considered within a common model.

The page-based model could be juxtaposed with a more abstract one, of the centre periphery differentiation, to produce a triple structure: centre - periphery - margin. One of our invited scholars, Krasimir Stanchev (Stanchev 2011), justly insisted on differentiating between the peripheral and the marginal. He offered the following distinction. The peripheral, unlike the marginal, pertains to the main text, belongs to the same author (or textual authority) and can become central. He distinguished between two kinds of peripheral, which can be detected by two different approaches: typologising and evaluative. According to the first approach, peripheral is the text which is so distant from a model that it approximates the model of another text or non-text. According to the second one, a text is peripheral when it follows the model strictly but remains of low quality or intensity. Our invited scholar distinguished between two kinds of marginality, too. First, one can add a note simply because there has been blank space on the margin. And, second, one can add a note to initiate a dialogue with the text. Having made these distinctions, Stanchev promoted his particular topic and thesis: "the literature of the Bulgarian Catholics of the $17^{\text {th }}$ century was marginal for the East and peripheral for the West, but it indicated the future model of Bulgarian development". It occurred that in some particular cases the marginal could become central: when a radical change of the model is anticipated and/or takes place. From this perspective, the marginal turns to be no more and no less than a degree of the peripheral, a latent periphery (just as the periphery is a latent centre). It is not difficult to discern in Stanchev's considerations the template of Yuri Lotman's semiotics of culture: one extrapolating the structure of a/the text upon the extra-textual (ir)reality, and one gravely relying on exploitation of data 
from the history of literature. ${ }^{11}$ Yet the experience of a medievalist dictated to modify the template's superstructure - to underline the difference between the marginal and the peripheral.

The ternary (and quantitative rather than qualitative) model centre - periphery - marginalia could be substantially enriched, given the experience of two works presented at the school - one on the variety of discourses, besides the dominating one, in the Soviet Georgian literature (Ratiani 2011) ${ }^{12}$, and the other on the wide gamma of degrees of canonicity in late antique and medieval Christian literatures (but especially in late medieval Bulgarian literature) (Miltenova 2011). The resultant elaborated version of the page metaphor could be juxtaposed with Pierre Bourdieu's theory of the field of (artistic) production (Burdio 2004) in order to produce a more complex and efficient model; and, besides, given the obvious (in)dependence of works of each field of production on two centres of "heteronomy" - political power and market - and on the centre of the "autonomy" of the corresponding field, to explain some particular cases of remarkable success of works marginal in more than one dimension (a 'biography' of such a work was developed in Grigorov 2011).

An actional model might help to overcome the typical one-sidedness imposed by the page-based model. A marginal note is not only added; the process of dissolution within a text may lead to an expulsion of certain fragments as marginal notes. Another paper delivered at the school unintentionally showed (Kuzidova-Karadžinova 2011) that the marginal is subject to the dialectic of inclusion and exclusion. The observation of the process of translation and a sequence of translations or different versions of one and the same work could support this notion. The marginal could be identified with the lost and with the acquired via translation; with a by-product of translation. The translator's notes present one possible materialisation. Sometimes the translation of a text might serve only as an excuse to articulate something on one's own. In this drastic case the translation itself turns to be the marginal.

The creation of a dynamic model of the marginal without abandoning the page metaphor, or archetype, seems to us most apt on the basis of the so called "genetic criticism", if we are to resist within the field of literary criticism. Let us take the "marginalist economy of textual genesis" launched by Daniel Ferrer, for example: its main subjects are the marginal notes as textualised intervals between texts read by a writer and texts that are (not) to be written by him. ${ }^{13}$

Now we closely approach the inter-agent or even inter-personal perspective on marginality. ${ }^{14} \mathrm{~A}$ paper was held on how a Canadian painter and writer pled for the cultural heritage of some ingenious Indian people in the state of British Columbia and how she employed their artistic traditions in her own art (Álamo Martín 2011). A question was posed from a listener: patronising someone marginalises him, doesn't it? Then Picasso's instrumentalising of African primitive art was recalled and another question was posed: whether the ambiguity (of neither full identifying with someone nor detached instrumentalising of his or her achievements) was the most dangerous mode of behaviour. "Dangerous" was meant in the sense of the moral vulnerability of attitude and of its marginalising effect on the counterpart. ${ }^{15}$ Our speculative attention was brought to the fol- 
lowing identification of the marginal: with something which or someone who is neither a mere means, nor a goal (neither it nor Thee). ${ }^{16}$

Marginality seems to be a kind of in-between-ness.

As I already said, materiality of the text-and-margin was much easier to ignore than their spatiality. The reminiscence of textual margin involves recalling the material (paper, parchment, ink and so on) and decoration of the page. For centuries (during the Middle Ages) and for decades (during the lifetime of experimental modernism) literary works have been transmitted in an intermedial ambience, and this multi-sensory milieu has been either interiorised as synaesthesia and ekphrasis or expelled outside the sheet of paper. This aspect of marginality in and for literature was attended in three papers only (Cleminson 2011; Álamo 2011; Rakjovsky 2011); it is noteworthy that only one of them was delivered by a medievalist scholar. (Moreover, in a paper, devoted to the acrostic and to its ambiguous marginality - it occupies the edge of the field of vision but expresses the essence, (Petrova 2011) - its visual and material aspects were completely disregarded.)

Let us examine the intellectual archetype of the page once more. We are urged to think in spatial and visual terms and metaphors and, what is more, in the terms of measured space (that is, space subject to geometrisation and geographisation). But, at the same time, we are invited to conceive and employ the space-time opposition. And in fact the archetype of the page introduces not only visual but tactile metaphors. The marginal, therefore, could be conceived as a 'spatial frame near/beside/across/around a temporal flux'. But it could be recognised in the opposite side, too: the marginal could be associated with the fluent, immeasurable or ephemeral within a regularised, measured, hierarchical and probably static world. Both ideas could be supported by the appearance of an illustrated manuscript page. The marginal is sediment or moving sands.

The sediment could attain shape. Architecture could be the marginal in and for literature. To my fancy, the following notion of the marginal would be suitable: marginality is what is on the verge between the visible and the invisible, and what makes the core (the non-marginal) look 'natural', coherent, and core by nature. In this sense literature is the marginal for and in architecture.

Before abandoning the centre - periphery scale, let us try to maximise the differentiation within it. For this purpose I shall employ an analogy. The classic, the mannerist, the epigone and the plagiarist form a sequence which could have its projection on the page: the archetype or referent of the work (in fact the centre), the beforehand text (the periphery), the margin and... the outside of the sheet of paper. ${ }^{17}$

The page metaphor ${ }^{18}$ suits the text-centric approach to literature. It leaves the reader half-objectified, assigning him to the margin. Permission into the boundary zone appears to be the only possible extent of recognising and accepting the Other into the Self.

2. If we try to ignore the centre - periphery opposition, the marginal would not be identified with a degree of the peripheral and would appear as something different. It would be, for example, the element which: a) introduces, b) leads away from, c) accompanies, d) sets the conditions/the rules of reading the non-"marginal". An example for (d): the strategy of narrating and representing in the $19^{\text {th }}$-century realism - one which suc- 
ceeds in imposing the illusion that what it represents "corresponds" to "life", to "reality"; that what is represented is 'natural', non-intended, unmade. Now, we may try to use the following definition: The marginal occurs to be the factor or element which manipulates us to perceive the 'made' as 'natural'. "The factor... which" could be personified: such agents of manipulation represent themselves the narrator and the implicit author. They pertain to the domain of the "Marginal for/in the literary text". The analogous agent in the realm of the "Marginal in/for the book" is the commentator (scholiast). But let us put the personifications of the marginal aside. Let us remind the etymology of the term 'margin'. It is in-between but not in the middle. It could be associated with the boundary where the opposites of a spectrum meet.

This notion of the marginal dangerously approximates the domain of another notion, of frame.

3. It is quite probable that I confuse the 'marginal' with what is on the edge of visibility and is more invisible than visible (and the marginal being more visible than invisible). I suppose that introducing the concept of 'effort' here will help to identify the marginal more definitely. Things exist which escape attention, which are difficult to focus even if we make effort; and other things exist, which escape attention but which we succeed in focusing when certain efforts are made. The 'marginal' belongs to the second group: it is the graspable un-grasped. Let us exemplify this notion of the marginal by placing it in the temporal perspective. First, some things are too new to be noticed. Second, there are things which are too well known to be explicated: they pertain to the so-called tacit knowledge (Michael Polanyi) which, in fact, makes communication in general and reading in particular possible ${ }^{19}$ Third, we may underestimate an inert phenomenon representing itself a potential connection with the past and the future; perceiving it/thinking of it as (of) useless "rubble", we are blocking our perception for its openness towards past and future and, of course, we are marginalising it. ${ }^{20}$

Being situated in the zone of the graspable but un-grasped, the marginal might escape pressure and preserve its freedom, which is probably the main asset of marginality (as a paper on the marginality of Bulgarian academic discourse on Russian émigré culture suggests: Petkova 2011).

4. We are somewhat confused when we try to define the marginal within a risomatic world model. It could probably be identified with what falls outside (or beside) the felicitous chain of territorialisations and de-territorialisations; the sedentary, in contrast to nomadic; the orderly (reducible to a pattern of spatial symmetry), in contrast to chaotic; the typical, in contrast to singular.

Sometimes the textual or media archetype of conceiving marginality - the topography of a (manuscript) page - urges us to abandon the central - marginal correlation. Such is the case, for example, with the topography of page in some manuscripts (both drafts and fair copies) of Walter Benjamin (Giuriato 2004). "Marginality manifests itself in two ways: first, in the topography of the manuscript to the degree that the margins are a space where the interior is exposed; second, in the physical gesture of folding the manuscript, making manifold writing possible in the literal (and manual) sense of the word. The gesture of writing thus gains influence over the semantics of the written and in this case rep- 
resents a marginal writing scene ${ }^{21}$ in which the text continually exposes itself" (ibid: 202-203). "The marginal note in Benjamin's work develops neither a segregated accidentality of the written that could entirely be integrated into the main text, nor a vertical hierarchy of (self)commenting meaning, sanctioning the order of the text and the subordination of the parergon. The folding of the manuscript is thus not simply a technical preparation, nor are the marginal notes just a supplement to the text, or simply a correlative, but the inner exposition of writing as a gesture that cannot be completed" (ibid: 206). Thus writing opens an infinite sequence of relative deterritorialisations (in the sense of Deleuz and Guattari).

Can we attribute this kind of de-centred writing to modernist experimentalism and modernist fusion of representative and private only? The already mentioned lecture of Ralf Cleminson (2011), "Margin as Text", offers a de-centralising epistemic perspective (margin can serve not as a margin but as a field for separate text) and attends to ambiguous cases: of commentary occupying not the margin but a parallel text column; of text "still" in large letters but literally marginalised ${ }^{22}$. Of course, regarding them similar to the case with Benjamin's manuscripts would be a hasty judgement. I would suggest that we have rather a system-supporting fluctuation in the representational amount assigned to different hierarchical positions ${ }^{23}$ (and even not mutual replacement) than loss of hierarchy and infinite unfolding. Yet the electronic texts offer a set of links to hypertexts instead of placeable paratext(s), it refers to different files "without visual status"; the endnotes being the only trace from a visual structure anchoring the text (given the contingency of the text - screen relation) ${ }^{24}$ It seems that "medial" marginality disappears..$^{25}$ I am tempted to see a kind of intermediate stance in Benjamin's unfolding manuscripts: between the topography of a misbalanced hierarchy availed by some medieval manuscripts and the non-'spatialisable' flow of e-text.

5. We may approach the problem bearing in mind our empirical experience as literary scholars. Which are the objects of interest in literary criticism that we may regard as marginal? We can regard as marginal: a) notes and pictures on printed and handwritten book margins; b) all kinds of paratexts (title, epigraph etc.); c) all kinds of un-marked positions within a text (starting with what cannot be identified as the text beginning and end); d) all kinds of unmarked positions within the literary field (works of average or low quality, writers considered epigones or second-hand, works and writers that had no conspicuous relation to the great ones); e) all kinds of boundary positions (between genres, between fiction and documentary, high and $l_{0}{ }^{26}$, poetry and graphomania, literature and everyday wording ${ }^{27}$ ). It seems that there is a contradiction between (b) (paratexts) and (c) (unmarked positions) - given the fact that paratexts are marked, i.e. they mark (point at) their own position. The contradiction is false. Paratextual elements/units are outside the text or on its border. It becomes clear that when the viewpoint or the distance changes different things can be recognised as marginal. I have just mentioned that the paratextual elements/units do mark their positions. Here we may assume that the 'material' which is to be used in paratext has or acquires the characteristics of a 'marker'. And there is, correspondingly, such a 'material' which contributes to de-marking the position it is introduced into, a 'material' which makes the position invisible or ignorable ${ }^{28}$. It should 
be 'material' introduced with the intention of detracting attention; or material detracting it devoid of intention. So we may define the marginal as what remains, after all positions "that matter" are outlined. It is obvious that it will constantly shrink. But the implicit hierarchy we are building, while making it retreat, does constitute it. ${ }^{29}$

If we leave the page metaphor which conceptualises our thinking of the marginal it would be easier to catch the marginal in terms of temporality. Thus, A. Alexieva (Aleksieva 2011) spoke about the "teachers' poetry" within the $19^{\text {th }}$ century Bulgarian literature. It experienced a short momentum in the mid- $19^{\text {th }}$ century, and then rapidly lost popularity and was even stigmatized, since it was "helpless verse-making" and expressed loyalty to the sultan. It became unacceptable for one more reason - it modelled local chronotopes, and not the supra-local of the emerging modern nation. If we try to extract another definition of the marginal from here, we would say that it coincides with the short-lived which, in addition, does not affect the subsequent development. It might be said that the teacher's poetry exercised only a 'negative' effect, serving as an object from which to detach. Returning to spatiality, we would say, next, that the 'marginal' within the live-space of a national community is the local (and the ethno-national would have been the 'marginal' within a supra-national imperial order), the every-day and the intermediate between the community under construction and the individual. Teachers' poetry is marginal insofar it falls outside the mainstream, not being within it during the preceding epoch as well: it is a phenomenon of the short-lived 'in between' period associable with Enlightenment, period of enlightened local civil communities, after the middle ages and before the Romanticism of the national revolution. It is a kind of temporal marginality, of in-between-ness, which does not recognise the particular profits of a marginal position: contrary to, quite characteristically, the avant-garde which had adopted what Renato Poggioli called the conscience and strategy of agonism (" $[\ldots]$ this immolation of the self to the art of the future must be understood not only as an anonymous and collective sacrifice, but also as the self-immolation of the isolated creative personality" (Poggioli 1968:67-68)). But we ought to differentiate between marginality as an unwanted and even un-supposed destiny and as a self-affirmative and self-distinguishing choice, on the one hand, and marginality as an inherent yet conscious mode of experiencing the world and the self, on the other hand. I have in mind the so called 'medieval man'. "Most people today consider that man is at centre of an ethnocentric world system, both politically and aesthetically. In contrast, the people of the Middle Ages saw themselves at the edge, the last ageing dregs of a falling-off of humanity, the dissipated end of a Golden Age eagerly awaiting the Last Judgement." (Camille 1992:53). ${ }^{30}$ One more dimension of 'medieval man' marginality: he is chronically trespassing against a borderline constitutive for self- and world-order, the one between sin and virtue, or is gliding on its verge, as Regina Koycheva's paper on marginality in the chronotope of the Old Bulgarian commemorative hymnography reminded us (Kojčeva 2011).

The enumeration based on empirical experience could go on. Yet we anticipate the following: any structural unit and any structural factor could appear as or be marginal - for a period of time, from a certain standpoint. It would be apt to speculate on and conceptualise different modes of marginalisation and de-marginalisation. 
6. It would be much easier to identify the marginal disregarding literature and then to make account on how literature represents, instrumentalises, and creates it (it or its image). The "feminine" would serve a good example. And everything that does not coincide with any of the poles in a dy-, try- and whatever poled contradiction/constellation, and which we do not tend to identify with its solution or synthesis. An example: Bulgaria is neither East nor West (and it could hardly achieve or represent a kind of synthesis of those), ergo Bulgaria is marginal. Marginal is the fact of non-belonging to any position recognisable as a 'pole' in a constellation.

Thus understood, marginality could be a geopolitical, geocultural, geopoetical ${ }^{31}$ condition. It is an aspect of marginality caught in the recently coined historiography and culturology term "Balkanism". In a wider sense, "Balkanism" is as old as the Roman historiography and may be older: in his Annals Tacit wrote of Armenia and Armenians: "This had been of old an unsettled country from the character of its people and from its geographical position, bordering, as it does, to a great extent on our provinces and stretching far away to Media. It lies between two most mighty empires, and is very often at strife with them, hating Rome and jealous of Parthia." (Tacitus 2 [56]); "Besides, the Armenians in the fluctuations of their allegiance sought the armed protection of both empires, though by their country's position, by resemblance of manners, and by the ties of intermarriage, they were more connected with the Parthians, to whose subjection, in their ignorance of freedom, they rather inclined." (Tacitus 13 [34]). Within the summer school, marginality as civilisational and geopolitical in-between-ness was approached in a paper inspecting manifestations of "Orientalism" and "Occidentalism" in the $19^{\text {th }}$ century Balkan cultures (Aretov 2011). The Balkan mentality seems to have been fluctuating between Orientalism and Occidentalism, between intimate adopting them and detached employing them. I have mentioned above that a work (Petkova 2011) touched upon the issue of the acceptability of marginality when it provides secure invisibility. Marginality could have one more (and much more important) asset: it could combine the experience of and the knowledge of worlds neighbouring and conflicting with each other $^{32}$ (A specific pride for one's marginality sees Aretov in the "The Spring of the White-Legged", 1873, a work from Petko Slaveykov firmly set in the national literary canon of Bulgaria. 'Marginal' is what falls in between the conflicting 'protagonists', what could employ the self-constitutive strategies of them both. However, it seems to be a local, guerrilla-like, employment, not a global one. ${ }^{33}$ ) Hence we are urged to utter two radically different notions of marginality: it is a zone of multiple potentialities (even more: one imbued with the generating principles of a multitude of systems) vs it is a zone of relative instability generated by a centre in order to perform its own stability. ${ }^{34}$ An agent could collate the two opposite conditions if (s)he/it succeeds in acquiring multiple levels of awareness, of understanding and acting on different epistemological levels.

It was the intimate interdependence between Orientalism and Occidentalism, the trace of marginality in both of them and the peculiar imbalance between them that intrigued me most. They form a characteristic interactive chain of marginalisation, of anxiety of marginalisation and of compensatory resistance against it. Defining mar- 
ginalisation, that is, the first step, Aretov departs from the idea that it might come as a self-marginalisation, as a result from adopting an outsider's frame of reference and selfconceiving through it; thereby he recalls the concept of 'self-colonisation" ${ }^{35}$ but he could have recalled the 'self-fulfilling prophecy' as well. The basic commonality between 'Orientalism' and 'Occidentalism' is the thrust to design the 'Other' as one's own negative and most probably inferior double. Both strategies are fed by a kind of dualism which is interrelated with a kind of reductionist universalism. If we assume the claim of Buruma and Margalit (Buruma/Margalit 2006) that Occidentalist ideas have Western provenance, we could claim that Occidentalism is doomed to be late, to be the belated pretender for dominance. And if we attend to the civil-and-metropolitan rhetoric of Orientalism and to the ruralist rhetoric of Occidentalism, we would associate the former with the ideology of a rising or already dominating former contact zone (or with the ideology of the polis), and the latter with the ideology of a descending or still dominated rural heartland (or with the ideology of the ethnos). One more asymmetry is worth mentioning: while Orientalism produces hegemony, Occidentalism pleads for destruction. I am inclined to think that both 'orientalism' ${ }^{36}$ and 'occidentalism' produce a variety of attitudes to dissolve the 'Other', or the others, or to displace them in different positions: peripheral, marginal, frontier-line, transcendent. Being (dis)placed in a given position, the animated fragment of 'otherness' is likely to experience some attitudes more frequently than other attitudes (thus we can expect that the transcendent would be hated or respected rather than neglected). The 'marginal' would be the strata which is negligible but which, in a time of danger, is seen as the transcendent enemy in miniature. One wonders whether the 'marginal' could be delegated the role of a mediator. Probably not; it is a role for what is positioned as a/the 'frontier-line', and the 'marginal' - by definition - skips, misses to take this position. If the 'marginal' is driven to the role of mediator during this fluctuating attitude toward it, it just means that it has changed its position, its strata, and has moved to the 'frontier-line'.

This conflict appears to be a cultural universal and is associable with a conflict between two semiotic orders: the conventional or liquid signification and the non-conventional or textbound signification.

We may return to the monistic hypothesis of the world which means not looking from the outside to the 'pole' or position with which we identify ourselves. We would identify our position with the truth and the other position would be the absolute evil. We would say that the latter has no right to exist, and we speak with it for the sake of tactical manoeuvre. The 'marginal' coincides with the other, with the evil.

Let us now look at the group of noble men fighting against evil. In fact only some voices here are of importance. And it wouldn't matter whether voices of men whose opinion is of no importance would be conformist or oppositional: they would be marginal. The 'marginal' coincides with whom or what is disrespected.

As the author of the paper on Orientalism and Occidentalism noted, conceiving oneself marginal can indeed make one marginal. Another participant re-accessed the issue on the example of $19^{\text {th }}$ and $20^{\text {th }}$ century Bulgarian culture (Hristov 2011). An involvement in a global literary economy conceived as an exchange of gifts between agents that 
are dominating and agents that are dominated could initiate a spiral of self-marginalisation. Synonymous to this involvement is subsuming to the feeling that you are obliged to be grateful for being civilised. In such a case your return gift is doomed never to gain recognition. ("[L]iterature is of value to the extent it gives valuable knowledge to the enlightened nations, the masters of the world. [...] One cannot claim that knowledge is valuable if the foreigners do not value it. [...] But if this is the case, then returning the gift of literature $[\ldots]$ produces a subject position [...] proving not the value of the nation that offers it but its inability to offer anything of value" (Hristov 2011:12). The civiliser becomes a hegemon. Following Ernesto Laclau and Chantal Mouffe, the lecturer defined hegemony as "any knowledge which is so powerful that it makes knowing the opposite indefensible", ${ }^{37}$

7. Of course, literature can make its theme or even its fate all these kinds of marginality and much more concrete ones. But sometimes it succeeds in representing the very vague idea of marginality. I mean modernist literature. A piece of it could reproduce what one of the participants (Tenev 2011) called "a machine for production of marginality", pointing at James Joyce's novels "Ulysses" and "Finnegan's Wake". Examining the ways in which the new characters are introduced into the modernist narrative, he realises that the marginal ones cannot be associated with indeterminacy and the central ones with determinacy. (On the contrary, the classical narrative is determinate as regards the central characters and indeterminate regarding the marginal.) What is more, the newly introduced characters could become indistinguishable from the central ones and from inanimate objects, thus subsisting chronic indeterminacy. The proper nouns, as guarantees of determinate identity, have "unstuck" from their usual referents in order to accompany the emerging "nebular" agents of subjectivity (neither central nor peripheral, neither animated nor inanimate). This mechanism of dissolving identities and criteria for ranking agents prevents the emerging of centre and thus marginality appears to occupy the central position. ${ }^{38}$

To summarise, in this paper I tried to demonstrate the heurism of the "page model" in conceptualising the marginal, especially when moved aside from the close context of medievalist textual scholarship. I also tried to show the interoperability between the notion(s) of (the) marginal and such phenomena and/or ideas as attitude (of mind), intention, will, (self)evocation, S/self(ness), O/other(ness), (self)alienation, (self)indoctrination and the like. In brief, I tried to outline what I had designated as topographical and rhetorical aspects of marginality.

I suppose that the diverse and sometimes contradicting notions of marginality, which I made articulate or stumbled upon, could be cohered via an understanding of marginality which does not simply merge, but synthesises its topographical and rhetorical aspects.

The texts delivered at Sofia summer school stimulated a monologue I find productive. Thus, whatever the deficiencies as regards direct approaching and unselfish interest in the theme, it has fulfilled the main task of a scholarly forum. 


\section{Notes:}

1. The programme is available on-line: http://www.ilit.bas.bg/bg/Summer_School_2010.php. The volume of the proceedings with the final versions of the texts (which are not the ones I refer to here) is already under preparation for print. In my paper I shall attend to or mention not more than half of the contributions (a conference review being just a side task for me).

2. Thus I shall be able to check the interoperability between my anticipations and the actual event.

3. I mind the book as a material form of the literary text. Here printed and handwritten books, scrolls and codices, and also epigraphs in the original sense might be considered. And the digital book and the different digital literary forms as well.

4. This domain of inquiry is exemplified by works like (Hughes 2001) which explore "how cultural centres require the peripheral, the outlawed, and the deviant in order to define and bolster themselves" (from the publisher's introductory note).

5. I borrowed the term from (Marginale 1983). The introductory paper of the volume outlined the main aspects of marginality in literature - stressing especially on historical, geographical and linguistic - noting the relativity of each (Vajda 1983:5-9); it seems that marginality of literature from sociological and aesthetical viewpoints (ibid: 10-12) had been much more frequently under focus.

6. These four domains intersect. Nevertheless I think they are almost equally distant from each other and that they cover the whole volume of literature's variability.

7. I recall here George Lacoff's idea of "conceptualising metaphor".

8. The hyphen leaving room for a prefix (para-, hyper-, meta-) is not less important than the root of the word.

9. I stumbled upon a recent work which thematises the turn (Geopoetiken 2010) after I had written my present work and almost completed it; and I am still not acquainted with such a groundbreaking work of the turn as J. Hillis Miller's "Topographies". I could link my preoccupation mentioned above with the move towards convergence of textual scholarship and literary criticism characteristic of the Anglo-American academia since the 1980s (see the anthology of Anglo-American works in textual scholarship (1980-2005) in Ecdotica 2009) - in fact a convergence theoretically coherent with the "turn" - but I cannot derive it from there (personal anamnesis does not support the suggestion).

10. An insightful and emblematic work synthesising theoretical, history of medieval literature and history of post-medieval literature perspectives (Georgiev 2004 [1990]) distinguished three genres of 'medially' marginal literature, or of marginalia, within Bulgarian literature of the Ottoman period. In citing it the only work "frontally" and plainly theoretically dealing with marginality at the forum devoted to marginality (Milchakov 2011:4) remained alone. I regard the first fact as one among several which witness for the fragmentation of the field of literary studies in Bulgaria (the main but not the only gully being that between medievalists and non-medievalists); and the second one as symptomatic for a characteristic malaise of scholarly forums: 
participants adjusting the thematic horizon of a forum to their personal interests and/or themes and not vice versa.

11. Remember Yuri Tynyanov's idea of literature dynamism: periodical movement of genres from the centre towards the periphery, together with underwater counter currents or weak side currents.

12. The 1970s situation (Ratiani 2011:10-11) seems particularly pointing.

13. Ferrer 2004. - The work contributes to a thematic (as all others are) issue of "Variants", the journal of the European Society for Textual Scholarship, devoted to "reading notes" (marginal as well as such produced by "extraction" and laid down not on margins). - Compare: "As Heather Jackson argues in her fascinating study on marginalia, notes in the margins are not only a 'responsive' type of writing that looks back to the text onto which the notes are grafted, they also look forward to an original expression of personality in many cases even to a new act of writing" (Van Mierlo 2004:147).

14. The page archetype supports this perspective: "marginalia assert the presence of a personality whose annotations [...] record 'a transaction between minds"' (Wim Van Mierlo cites H. Jackson in Van Mierlo 2004:147 (note 23)).

15. Compare with a similar concern in a recent book on marginality in French late $19^{\text {th }}$ and $20^{\text {th }} \mathrm{c}$. literature: “[ $[.$.$] gesturing towards cultural difference in no way guarantees$ dialectical engagement with it. Indeed, it is often an ambivalent move, entailing the pursuit of private goals - sexual, political, aesthetic - and the collateral exclusion of the Other" (Hughes 2001:8).

16. The discussion provoked by a paper devoted to a Canadian artist-and-writer's paintings made evident the faint interest in intermediality and the active one in intercultural communication. One more time the social dimensions of marginality vis-à-vis literature overshadowed the poetological ones. See about possible intersections between sociologically thoughtful and topographically aware literary study below.

17. But compare with the following type of three-level structure: biblical text - commentary - biblical quotations within the commentary's text (recalled by Margaret Dimitrova during the discussion after Ralph Cleminson's lecture). Which variant is more apt: to regard the commentary as marginalia and the biblical quotations as periphery or vice versa?

18. Note the problematic functionality of a very similar metaphor - I would call it folial or leaf metaphor.

19. One of the papers thematised the tacit knowledge invested in the so called current criticism and the heurism of discovering and articulating it for the history of literature: Mikkel 2011.

20. Thus, for example, a paper (Rakjovsky 2011) thematised the following issue: the works of $\mathrm{X}$ and $\mathrm{Y}$ are considered to witness that a certain style, movement and aesthetic epoch has begun; but in fact it is only the usually neglected background of their works, a background inhabited by works and authors doomed epigones, which makes the phenomenon un-occasional, "dense" and therefore real. What is more, one of these "epigones" (in fact a less talented or less adequately talented co-founder who 
was unable to overcome the preparatory phase) developed a technique which was sought after later, within the next style of the epoch.

21. "Rüdiger Campe has proposed the term "writing scene" for a type of writing that comprises three heterogeneous aspects, namely language (semantics), technical preparation (or instrumentality) and bodily gesture" (Giuriato 2004:199).

22. A rhetoric question from the public (Álamo Martín) was raised on whether this displacement of text by the commentary is similar (or probably prefigures, I would add) to the condition of modern literature, often overwhelmed by literary criticism. Unfortunately, the asserted statement was not followed by further speculations on the topic.

23. Roughly speaking, the higher in hierarchy could require less explicit attention; generally speaking, it is a possibility transposing the distrust in iconic representation from the qualitative (compare iconicity - an-iconicity; cataphasis - apophasis; visual beauty of the image - visual ugliness of the image) into the quantitative order.

24. I am postponing a careful examination of Cleminson's contribution.

25. If I am to speculate on the relation between such a disappearance and the condition of social etc. marginality (that is, of marginality outside the text), I would suppose its veiling function: it veils the persistence of hierarchy, persistence in a sort of a-spatiality (and therefore becoming both more elusive and more fundamental).

26. At least two papers dealt with a specifically ambiguous, between "high" and "low", stance: Modebadze 2011 on the drift of Soviet science fiction toward "high" literature and Aleksandrov 2011 on Margaret Atwood's dystopian novels' uneasy inbetween-ness (they are neither 'enough' "high" nor 'enough' popular).

27. A recent Bulgarian work on para-literature written by Evdokia Borisova, Plamen Shulikov and Yani Milchakov (Borisova/Šulikov/Milčakov 2009) is worth to be mentioned here; it investigates theoretical and historical aspects of Bulgarian literature's intersections with its school, beau-monde and mass culture ambience (which produced albums, popular songs brochures, dime-novels series etc.).

28. The corresponding category would fit well in an aesthetics which opposes the aesthetics of provocation.

29. We are used to think that, if a certain piece of artistic stuff is introduced on a marked position, it gains in weight, in significance. But the reciprocal is valid too: a piece of stuff could transform a position into a marked one. It is no coincidence that a position habitually perceived as marked could promote a disappointing stuff which would make the recipient's interest shrink, within a tendency to perceive as unmarked.

30. Dilyana Radoslavova's contribution (Radoslavova 2011) offered an even more interesting perspective on temporal marginality (as well as on its intersections with topographical, of different scopes), for it discussed the borderland and ambiguous seventeenth century in Bulgarian literature and language history (usually considered the last from the middle ages) and the dissemination and structure of its ambiguous genre protagonist, the Damaskini.

31. On geopoetics see Geopoetiken 2010 and works referred at there: White 1987: 272-293; Sid 2008 etc. Merging of conceptualisations of geopoetics (moreover, of its 
different versions (on them: Frank 2010:20-24)) with the conceptualisations of Edward Said and like could be fruitful (compare Frank 2010:27-31) but for reasons of clarity I am postponing it.

32. What Aretov failed to say explicitly (but what he certainly had in mind) is that a situation on the Bulgarian-made 19th century mental map emerges within which the Bulgarians are the 'centre' - being localised between the brutal (Asian) evil (the Turk) and the sophisticated European one (the Greek), "as in some variants of the sujet about Stoyan vojvoda".

33. But compare with the rise of Caliphate from the in-between of East Roman and Sassanian Iran empires: (non)marginality, taken only as a term of topographic description, has deficient explanatory force.

34. Diverse data could support the second one. The "lack of an alternative [...] prevents medieval joke-making from becoming subversive", including the consciously subversive text of marginal illustrations (Camille 1992:43). "Unlike Proust, Camus, and Genet, Loti, Gauguin, and Montherlant are not canonical writers. Yet the works of each of these authors, major and minor alike, express a cultural malaise in which the insufficiency of Self regularly awakens a desire to explore as well as to police the exotic horizon" (Hughes 200:7).

35. A concept revitalised, within the context of contemporary Bulgarian humanities, by Alexander Kyossev in the 1990s.

36. Note the move from the status of a proper noun.

37. The conditions of falling into marginality, choosing marginality, and professing it have been a matter of consideration in the paper of Amelia Licheva, devoted to writers' and literary scholars' condition in post-communist Bulgaria (Ličeva 2011). Here marginality is meant in its sociological sense. It is not difficult to associate the three stances mentioned with certain positions within an autonomous field of production ala Bourdieu. What I miss and what I fail to conceptualise here is a kind of sociology-free (up to the possible degree) and psychology-free intention-bound, volition-relevant personalist theory of literary marginality.

38. Another paper (Thurston 2011) approached the same basic condition differently, claiming that the poetics of modernism was in fact a poetics of a disaster; the trench, the world of war-born existence in parenthesis and in-between became the norm. - A study of medieval book illumination on the West (Camille 1992:18-26) reveals a semiotic overturn which resembles the negative of modernist overturn: it is after the $12^{\text {th }}$ century that the marginal images, which were amidst the body of the text before, emerge.

\section{References:}

1. Aleksandrov, D. (2011) The Postmodern Dystopian Novels of Margaret Atwood. // Paper, delivered at the "Marginal in/for Literature" summer school held in Sofia $6-10^{\text {th }}$ of June 2011 (pp. 1-18). 
2. Aleksieva, A. (2011) Poetičeski marginalia na Vŭzraždaneto: daskalskata poezija [Poetical Marginalia of the National Revival Period: The Teachers' Poetry] // Paper..., (pp. 1-12).

3. Álamo, M.R. (2011) Emily Carr's Writing and Painting: A Modernist Experiment of Interdisciplinary in the Margins. // Lecture, delivered at the "Marginal in/for Literature" summer school held in Sofia 6-10 $0^{\text {th }}$ of June 2011 (pp. 1-15).

4. Aretov, N. (2011) Strahŭt ot marginalnost i problemŭt za oksidentalizma v balkanskite kulturi [The Fear of Marginality and Occidentalism in the Balkan Cultures] // Lecture..., [1]-[12].

5. Borisova, E.; Šulikov, P. and Milčakov, J. (2009) Paraliteraturata. Tekstologija, sotsiologija, mediatori [The Paraliterature. Textology, Sociology, Mediators]. Veliko Tŭrnovo: Faber.

6. Burdio, P. (2004) Pravilata na izkustvoto: Genezis i struktura na literaturnoto pole./ Tr. by S. Atanasov, M. Velinova, A. Želeva, A. Robova. Sofia: Maison des Sciences de l'Homme et de la Société, 2004. [Translation of: Pierre Bourdieu, Les règles de l'art: Genèse et structure du champ littéraire, Paris, Seuil, 1998, 1992]

7. Buruma, I. and Margalit, A. (2006) Oksidentalizmŭt: Kratka istorija na antizapadničestvoto. / Tr. by G. Atanasov. Sofia: Kralitsa Mab.

8. Camille, M. (1992) Image on the Edge: The Margins of Medieval Art. Cambridge (Mass.): Harvard UP.

9. Cleminson, R. (2011) Margin as Text. // Lecture..., 46’30" [No print version available. Accessible via You Tube at http://www.ilit.bas.bg/bg/marginal literature_video.php]

10. Ecdotica (2009) Ecdotica. / Ed. by F.D. Corte et al.. Bologna - Madrid - Roma: Carocci, Vol. 6.

11. Ferrer, D. (2004) Towards a Marginalist Economy of Textual Genesis. // Variants. / Ed. by D. van Hulle \& W. van Mierlo, Amsterdam - New York: Rodopi, Vol. 2/3: Reading Notes (pp.7-18).

12. Frank, S. (2010) Geokulturologie - Geopoetik. Definitions- und Abgrenzungsvorschläge. // Geopoetiken: Geographische Entwürfe in den mittel- und osteuropäischen Literaturen, hg. v. M. Marszałek u. S. Sasse (pp.19-42). Berlin: Kadmos.

13. Geopoetiken (2010) Geopoetiken: Geographische Entwürfe in den mittel- und osteuropäischen Literaturen, hg. v. M. Marszałek u. S. Sasse. Berlin: Kadmos.

14. Georgiev (2004 [1990]) Pisaha ne samo da se znae [They Wrote Not Only to Be Remembered]. // LiterNet. / Ed. by G. Chobanov, Varna: Liternet, N 8 (57) (August 2004), http://liternet.bg/publish/ngeorgiev/statii/pisaha.htm

15. Giuriato, D. (2004) Folded Manuscripts: Walter Benjamin's Marginal Writing. // Variants 2/3 (pp.195-206).

16. Grigorov, G. (2011) "Šumi Marica" - ot oficializiraneto do marginaliziraneto i ["Shumi Maritsa" - From Officialisation to Marginalisation]. // Paper..., [1]-[17].

17. Hristov, T. (2011) The Gift of Literature: Global and Local in the Economy of a National Literature. // Lecture..., (pp.1-22).

18. Hughes, E.W. (2001) Writing Marginality in Modern French Literature: From Loti to 
Genet. Cambridge: Cambridge UP.

19. Kojčeva, R. (2011) Interpretacii na marginalnoto v starobŭlgarskata himnografija [Interpretations of the Marginal in Old Bulgarian Hymnography]. // Paper..., [1]-[17].

20. Kuzidova-Karadzhinova, I. (2011) Slavjanskata versija na "Žitieto na sv. Ilarion Veliki" ot Jeronim Blaženi [The Slavonic Version of Blessed Jerome's Vita Hilarionis]. // Paper..., (pp.1-17).

21. Ličeva, A. (2011) Perifernite zoni v literaturata: tekstove, ličnosti, konflikti [The Peripheral Zones in Literature: Text, Personalia and Conflicts]. // Lecture..., (pp.1-14).

22. Marginale (1983) "Marginale" Literaturen. "Marginal" Literatures. Littératures "Marginales". / Ed.by W. Bader, H.J. Lüsebrink, R. Sander. [A thematic issue of] Komparatistische Hefte, Heft 7. Bayreuth: Universität Bayreuth.

23. Mikkel, M. (2011) Contemporary Literature in the Knowledge of the Readers: the Example of the Estonian Literary Criticism of the Beginning of the 20th Century. /I Lecture...

24. Milčakov, J. (2011) Marginalnoto - opisatelna ili cennnostna kategorija? [The Marginal - a Descriptive or an Axiological Category?]. // Lecture..., (pp.1-9).

25. Miltenova, A. (2011) Marginalnost, intertekstualnost, paratekstualnost v kŭsnoantičnata i srednovekovnata knižnina [Marginality, Intertextuality, Paratextuality in the Late Antique and Medieval Literature]. // Lecture..., (pp.1-24).

26. Modebadze, I. (2011) Sovetskaja fantastika - "begstvo ot dejstvitel'nosti" ili...? [The Soviet Science Fiction - "an Escape from Reality" or...?]. // Lecture..., 1-16.

27. Petkova, G. (2011) Marginalizatsijata - dostatǔčnijat ezik v govoreneto za ruskata emigratsija v Bŭlgarija (1919-1940)? [Marginalisation - the Sufficient Discourse in Speaking of Russian Émigré Community in Bulgaria (1919-1940)]. // Lecture..., (pp.1-11).

28. Petrova, S. (2011) Akrostihŭt - izraz na sǔstnostta v periferijata [The Acrostic - an Expression of the Essence in the Periphery]. // Paper..., 1-10.

29. Poggioli, R. (1968) The Theory of the Avant-garde. / Tr. by G. Fitzgerald, Cambridge (Mass.) and London (Eng.): The Belknap Press of Harvard UP, s.a. [digital reprint of the 1968 edition].

30. Radoslavova, D. (2011) Graničnijat sedemnadeseti vek. Bŭlgarskata pravoslavna knižnina - fenomenŭt ot periferijata [The Marginal Seventeenth Century. Bulgarian Orthodox Literature - a Phenomenon from the Periphery]. // Paper..., 26'44" (http://www.ilit.bas.bg/bg/marginal_literature_video.php).

31. Rakyovsky, T. (2011) Kanonizirani Figuri-Marginalni Avtori: Ivan Mirčev, Ivan Grozev, D. Panteleev, Sirak Skitnik [Canonised Figures - Marginal Authors...]. // Lecture..., (pp.1-23).

32. Ratiani, I. (2011) Sovetskij totalitarizm i formy literaturnogo diskursa [Soviet Totalitarianism and the Forms of Literary Discourse]. // Lecture..., (pp.1-12).

33. Sid, I. (2008) Osnovnoj vopros geopoetiki [The Chief Question of Geopoetics] // Krymskij klub: Pervaja konferencija po geopoetike (Moskva, 1996), http://liter.net/geopoetics/penin.html. 
34. Stanchev, K. (2011) Literaturata na bŭlgarite-katolitsi: marginalna za Iztoka, periferna za Zapada, no indicator za büdeštija model na bŭlgarskoto razvitie [The Literature of Bulgarian Catholics: Marginal for/from the East, Peripheral for/from the West, but Indicative of the Future Model of Bulgarian Development]. // Lecture..., (pp.1-16).

35. Tacitus Annals. // The Works of Tacitus. / Tr. by A.J. Church and W.J. Brodribb [18641877], http://www.sacred-texts.com/cla/tac/index.htm\#section_000

36. Tenev, D. (2011) Neopredelenost i marginalnost pri vǔveždane na personaži vŭv fiktsionalni proizvedenija [Indeterminacy and Marginality in Introducing Characters in Fiction] // Lecture..., (pp.1-18).

37. Thurston, L. (2011) David Jones: In Parenthesis, At the Margin. // Lecture..., (pp.1-16).

38. Vajda, G.M. (1983) Einleitung: Marginale Literaturen. // Komparatistische Hefte: "Marginale" Literaturen.../ Hg. J. Riesz, R. Taylor, T. Bleicher, Bayreuth: Universität Bayreuth, Heft 7 (pp. 5-14).

39. Van Mierlo, W. (2004) Reading W. B. Yeats: The Marginalia of T. Sturge Moore. // Variants 2/3 (2004) (pp.135-172).

40. White, K. (1987) Éléments de géopoétique. // Ibid: L'Esprit nomade. Paris: Grasset, (pp. 272-293).

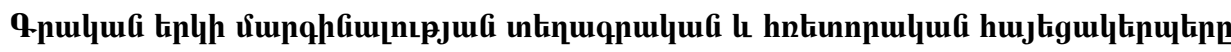

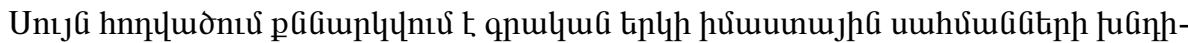

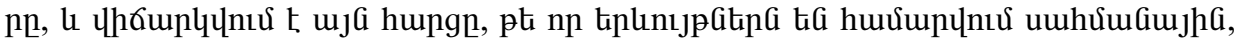

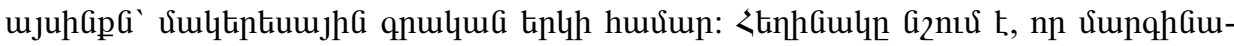

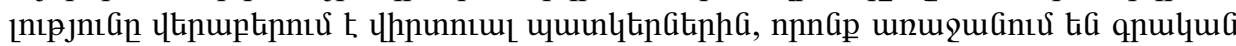

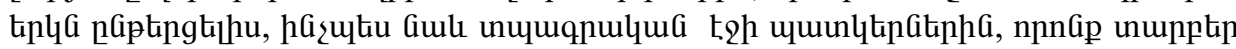

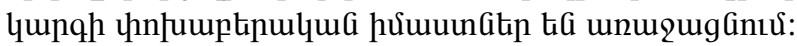

